\title{
PHARMACEUTICAL PREPARATION AND DETERMINATION OF QUALITY STANDARDS OF SARASWATARISHTA: A HERBO-MINERAL ALCOHOLIC FORMULATION
}

\author{
Aishwarya Krishna Koyande ${ }^{1 *}$, Swati Shankar Gadgil ${ }^{2}$ \\ ${ }^{1}$ PG Scholar, Department of Rasa Shastra Evam Bhaishajya Kalpana, College of Ayurved, Bharati Vidyapeeth \\ (Deemed to be) University, Katraj, Pune, Maharashtra, India \\ ${ }^{2}$ Assistant Professor, Department of Rasa Shastra Evam Bhaishajya Kalpana, College of Ayurved, Bharati Vidyapeeth
}

(Deemed to be) University, Katraj, Pune, Maharashtra, India

Received on: 13/08/20 Accepted on: 25/09/20

\author{
*Corresponding author \\ E-mail: aishwaryakoyande@gmail.com
}

DOI: 10.7897/2277-4343.1105147

\begin{abstract}
Saraswatarishta is a herbo-mineral hydro alcoholic formulation prescribed for various memory and sleep related disorders as well as a brain tonic. It is a unique formulation where the presence of swarna during the fermentation process may be responsible to manifold the action of remaining herbal drugs. Though the formulation is prescribed widely and available in the market with different varieties, there is a lack of documentation regarding the standard operating procedure and quality of the product. In the present study, Saraswatarishta and Swarna Saraswatarishta were prepared following standard operating procedure. Both the formulations were subjected to physico-chemical tests and values were found within the normal limits of arishta preparation from Ayurvedic Pharmacopeia of India. The sample of Swarna Saraswatarishta was analysed to check the presence of swarna using the ICP-MS technique. It was found below the level of quantification which interprets the absence of swarna in the formulation. This is the first and foremost report regarding the presence of Swarna in Swarna Saraswatarishta.
\end{abstract}

Keywords: Arishta; hydroalcoholic formulation; brahmi; gold; Bacopa monnieri; traditional system of medicine

\section{INTRODUCTION}

Ayurveda is a traditional healthcare system originated thousands year back. The medicine system of Ayurveda comprises of plant base, mineral base and animal base system of medicine that meets more than $50 \%$ of the healthcare needs of India ${ }^{1}$. It comprises various types of dosage forms according to the modalities. Sandhana Kalpana is one of the dosage forms practiced since Vedic period. The basic pharmaceutical principle in Sandhana kalpana is to extract active constituents of drug through a biochemical process of fermentation in a mildly self-generated alcoholic medium. This ensures extraction of both water and alcohol soluble constituents. Asava and arishta are most popular dosage forms prepared using herbal juices and decoctions which undergo fermentation in favourable conditions to achieve long shelf life, quick action, and high therapeutic effectiveness. Alcoholic preparations and their actions are innumerable depending upon the ingredients, their combinations and method of preparation.

Saraswatarishta is a hydro alcoholic compound formulation of Bacopa monnieri. The reference of the formulation is described in rasayana chapter of Bhaishajya Ratnavali ${ }^{2}$. As per the text, the formulation contains swarna (gold) as an ingredient. It is one of the famous and frequently practiced Ayurvedic Medicines for numerous mental health issues, sleep disorders and as a brain tonic (Medhya rasayana). Considering the demand of the formulation researcher surveyed for its availability in the market. After surveying, three main varieties of the formulation i.e. Saraswatarishta (contains no swarna/ gold), and Saraswatarishta (with gold) or Saraswatarishta (swarnasanskarit) were found available. More than ten pharmacies produce this formulation. Till date, the standardization of Saraswatarishta (without gold) is done based on presence of Centella asiatica Linn (brahmi) ${ }^{3}$. The physico-chemical values of Saraswatarishta (without gold) are developed followed by its free radical scavenging activity ${ }^{4}$. Saraswatarishta (without gold) also has been evaluated for its anti-convulsant activity ${ }^{5}$, improving learning and memory ${ }^{6}$ and anti-epileptic activity ${ }^{3}$. Saraswatarishta (with gold) is found effective on animals with behavioural despair proving antidepressant activity ${ }^{7}$. Apart from the above stated research work there is no report stating the development of standard operating procedure (SOP) of the formulation and presence of swarna.

This gave us the impetus to work on this formulation and generate data regarding pharmaceutical preparation details and quality standards of both the varieties. Hence to generate and validate the data of Saraswatarishta and Swarna Saraswatarishta, this study was designed.

\section{MATERIALS AND METHODS}

\section{Pilot batch preparation}

To develop standard operating procedure for this formulation; pilot batch in triplicate was prepared, tested, and analysed.

\section{Methodology of pilot batch preparation}

Before starting the preparation of main study drug, the decision of pilot batch preparation was taken since there is no standard operating procedure available in Samhita or AFI and published papers for this formulation. As per the classical reference, Brahmi was used in fresh form for preparing Saraswatarishta. Three different samples of Saraswatarishta (using one litre kwatha each) were prepared to develop the SOP for study drug. Swarna was not 
added during pilot batch preparation. All the details about pharmaceutics were noted and followed during study drug preparation. The three samples were analysed as per general API guidelines (excluding estimation of methanol content) to identify physico-chemical constants. SOP developed during this process was followed for the study drugs.

\section{Collection, identification, authentication of herbal drugs}

Brahmi and Aadraka were collected from authentic source in fresh form and were identified by botanist of the institution.

All the other ingredients were procured in whole (Akhanda) dry form. They were collected from well-known authentic source of Pune and authenticated from renowned pharmacy of Mumbai.

Khanda Sharkara and honey were also collected from the authentic source from Pune.

\section{Authentication of gold}

Swarna is one of the ingredients of Swarna Saraswatarishta and as per the textual reference it was used in patra (thin sheet) form. The 24 Carat pure gold sheets were procured from local authentic hallmark certified jeweller of Pune.

\section{Preparation before fermentation}

All the dry whole drugs were pounded using mortar pestle and sieved through $60 \mathrm{Mesh}$. The fresh drugs i.e. brahmi and Aadraka were cleaned to remove physical impurities. Both were thoroughly washed using tap water, drained and chopped into smaller pieces. The Prakshepaka drugs were powdered using grinder and sieved through 80 Mesh.

The khanda Sharkara (compound sugar) was pounded, converted into powder, and sieved.

The fermentation pots, instruments and other equipment's were rinsed using hot water, dried in sunlight, and fumigated using Dhoopana drugs (Shuddha guggulu, Vacha choorna, jatamansi choorna, Vidanga choorna, all in equal quantity)

Dhataki Jala was prepared using the classical reference ${ }^{8}$. Dhataki pushpa were obtained in whole form and converted into coarse powder before use. It was taken in $100 \mathrm{~g}$ quantity and soaked in $1000 \mathrm{ml}$ of Shrutasheeta Jala (boiled and cooled water) for 24 hours. Then the mixture was macerated, filtered using cotton cloth and kept aside.

The sheets of Swarna were subjected to Samanya shodhana using classical reference of Rasaratna samucchaya. 24 gm of raw gold biscuit (swarna) was transformed into thin sheets of approx $5 \times 3$ $\mathrm{cm}$ dimension and $90 \mu \mathrm{m}$ thickness measured using micrometer screw gauge. Thus, total twelve sheets were acquired. The shodhana was carried using quenching method in five different liquid Medias. All the five liquid Medias i.e. til tail (Sesame oil), takra (buttermilk), Gomutra (cow urine), kanji, Kulattha kwatha (decoction of Dolichos biflorus Linn) were taken in equal quantity i.e. $200 \mathrm{ml}$ in separate glass bowls for each time of shodhana. Each swarna sheet was held in a tong and allowed to heat using pressure gun till it turn red hot in appearance. Then this red-hotsheet was quenched in first liquid media i.e. til taila for the first time. This procedure was conducted for total seven times using til taila. Similarly, the procedure was repeated using rest four liquid Medias in sequence. The liquid Medias were changed for each time of quenching and the volume of remaining liquid was measured. The loss observed was $5-7 \%$. At the end of the procedure, the swarna sheets were washed with hot water, wiped using tissue paper, weighed, and stored in a glass container. The Shuddha Swarna sheets were ready for further use in the formulation of Swarna Saraswatarishta.

\section{Preparation of Saraswatarishta and Swarna Saraswatarishta}

The preliminary step for the preparation of Saraswatarishta and Swarna Saraswatarishta is preparation of kwatha and it was decided to prepare in common. All the pounded and chopped drugs were added in thick bottom steel vessel of $70 \mathrm{~L}$ capacity. Potable water in $12 \mathrm{~L}$ quantity was added into the vessel and level was marked. The remaining quantity of water $(36 \mathrm{~L})$ was added and the mixture was allowed to heat on medium flame. The kwatha was reduced to $1 / 4^{\text {th }}$ of its original quantity $(12 \mathrm{~L})$ and filtered using a clean cotton cloth in a clean fumigated stainlesssteel vessel.

The powdered sugar was mixed in the warm kwatha, mixture was stirred till the sugar dissolved completely and it was filtered to remove the physical impurities observed in the mixture. Then the mixture was divided into two equal parts for preparation of Saraswatarishta and Swarna Saraswatarishta and allowed to cool. Prakshepaka drugs were added into both the Sandhana pots. The equally divided kwatha mixture was poured into both pots followed by addition of Madhu and Dhataki Jala in the mentioned quantity (Refer Table 1). The mixture was stirred using stirrer.

In case of Swarna Saraswatarishta the Shuddha Swarna sheets were added into the pot and observed floating on the surface. Hence to make sure the maximum contact of sheets with the fermentation mixture, they were tied using heavy china clay pieces; fumigated and added into the fermentation pot.

The fermentation pots were sealed using cotton cloth smeared with multani mitti (fuller's earth clay) and kept in a clean, dry, dark place for the duration of thirty days.

On $31^{\text {st }}$ day, both the pots were opened to check the status of the fermentation process. The confirmatory tests were performed interpreting incompletion of the process. Hence, it was decided to continue the process of fermentation for further one month. After a month, the fermentation pots were re-opened, and the completion of fermentation was confirmed.

Both the formulations were filtered using clean cotton cloth in separate vessels. The formulations were stored separately in amber coloured bottles for further use. In case of Swarna Saraswatarishta the Swarna sheets were removed after filtration, cleaned using warm water, dried and weighed.

\section{Analytical parameters}

The prepared samples of Saraswatarishta were analysed for organoleptic tests (colour, odour, taste, texture) followed by physico-chemical tests i.e. $\mathrm{pH}$, specific gravity, alcohol percentage, total phenolic content, total solids, total sugar content, microbial load.

\section{Methodology used for physicochemical tests}

\section{- $\mathbf{p H}$}

The $\mathrm{pH}$ of formulation was measured using digital $\mathrm{pH}$ meter. It is the measure of hydrogen ion concentration, a measure of the acidity or alkalinity of a solution. The $\mathrm{pH}$ scale usually ranges from 0 to 14 . A pH less than seven are acidic, while those with 
$\mathrm{pH}$ greater than seven are basic or alkaline. Arishta formulations are acidic in nature as its normal value ranges between 3-5.

\section{- Specific gravity}

It is the ratio of density of substance to the density of a reference substance (water). The specific gravity of Saraswatarishta was measured using pycnometer. The specific gravity was calculated by weight of pycnometer with distilled water over the weight of pycnometer with sample.

\section{- Alcohol content}

The ethanol content of a liquid is expressed as the number of volumes of ethanol contained in 100 volumes of the liquid, the volumes being measured at $24.9^{\circ} \mathrm{C}$. The alcohol content was calibrated using specific gravity method.

\section{- Total phenolic content}

It was measured as gallic acid equivalents. Briefly, $5 \mathrm{ml}$ of Folinciocalteau reagent was added to $1 \mathrm{ml}$ sample followed by addition of $4 \mathrm{ml}$ of $1 \mathrm{M}$ sodium carbonate. It was incubated in dark place at room temperature (30 $\mathrm{min})$ and measured absorbance at $765 \mathrm{~nm}$. A gallic acid standard curve $\left(\mathrm{R}^{2}=0.99\right)$ was used to measure the phenolic content and was expressed as $\mathrm{mg} / \mathrm{g}$ of dry mass of gallic acid equivalents.

\section{- Total sugar content (Brix)}

The sugar content was calculated in Brix using digital refractometer. The upper opening of the refractometer was cleaned with distilled water. Then 4 to 5 drops of the sample (28 $\pm 2^{0} \mathrm{C}$ ) were placed on the flat opening. The reading was noted.

Further the sample of Swarna Saraswatarishta was subjected to ICP-MS technique to detect the presence/absence of gold and percentage (if present) at renowned laboratory of Pune.

\section{- ICP-MS: (Inductively coupled plasma mass spectrometry)}

The technique of ICP-MS was used to detect presence/absence of swarna and if present then quantify its amount from the sample of Swarna Saraswatarishta. The liquid sample $(0.5 \mathrm{ml})$ was digested using microwave digester and then reconstituted up to $50 \mathrm{ml}$ in the de-ionised water to stabilize elements in the solution. The prepared sample was introduced to nebulizer of the ICP-MS instrument for detection of metallic content (gold) in the sample.

\section{RESULT}

The drug source of fresh drugs and other essential ingredients were common for preparation of both the samples. The time required to prepare $12 \mathrm{~L}$ kwatha was 6.15 hours. The addition of Sharkara in kwatha resulted in increased volume of the mixture. The incompletion of the fermentation process was confirmed on day thirty by observing the bubbles on the top layer of the formulations and lighted candle placed on the surface of fermentation pot was burned out. These confirmatory tests were also repeated on day sixty interpreting completion of the fermentation process. The $\mathrm{pH}$ noted on day thirty $(4,3.6)$ as well as day sixty $(3,2.9)$ showed major difference.

In case of both the samples, percentage loss observed (after filtration) was $12 \%$. After completion of fermentation process of
Swarna Saraswatarishta, the Swarna sheets were removed and weighed. Zero percent loss was recorded in the weight of swarna sheets.Values for organoleptic parameters and physico-chemical constants of Saraswatarishta and Swarna Saraswatarishta are thus generated and reported in Table 2 and 3, respectively.

\section{Results of ICP-MS}

The sample of Swarna Saraswatarishta was analysed using ICPMS technique where the amount of swarna was found below the level of quantification.

\section{DISCUSSION}

Saraswatarishta is the only formulation from arishta class in rasayana chapter of Bhaishajyaratnavali ${ }^{2}$. The drugs used in the kwatha and prakshepaka were collected in whole (Akhanda) form to maintain the purity. The reason for pounding the prakshepaka drugs just before adding them is to sustain the active constituents in the form of volatile oils. The prakshepaka drugs are major portion in the formulation. Apart from therapeutic effects, they also impart attractive colour and odour to the formulation ${ }^{9}$.

The classical reference has quoted the details about use of Bhajana (vessel) for preparation of the formulation recommending the use of gold vessel (Swarnakumbha) or earthen vessel (mrutpatra). In this study, china clay pot was considered as an ideal vessel, as it is commonly used for the preparation of asava arishta. Earthen pots have limitations while handling like early breakage, oozing out of the formulation, interference in the temperature which also affects the process of fermentation. It was observed that earthen pot causes evaporation due to its porous nature which resulted in limited solubility of compounds ${ }^{10}$. Whereas the china clay/ceramic pots act as inert material and the inside formulation gets least affected by the atmospheric change. Hence to avoid the hurdles, china clay pot was preferred.

The classical reference mentions two forms of swarna, i.e. gold vessel (Swarnakumbha) or thin sheets of gold (Swarnapatra). Apart from these two forms, API mentions use of gold salts (Swarnalavan). However gold salts (auric chloride), the chlorides (lavana rasa) may hamper the fermenting process as it seizes the growth of micro-organisms responsible for fermentation ${ }^{10}$. It is observed that the pharmaceutical companies add swarna bhasma (gold ash) in Saraswatarishta preparation. The use of bhasma form was well known and practiced since the time of Nagarjuna $(800 \mathrm{AD})^{11}$. However; in the ingredients of Saraswatarishta, gold sheets are mentioned instead of bhasma. Use of raw gold and bhasma (gold ash) makes a great difference as both are different forms of gold and are differently processed. The qualitative analysis of swarna bhasma comprises $90-95 \%$ of Au and other metals (Fe, As, $\mathrm{Si}, \mathrm{Al})$ as the process of Bhasmikarana (incineration) of Swarna also includes use of different herbal drugs as well as minerals ${ }^{12}$. Thus, it might not be rationale to use swarna bhasma.

In the present study, swarna was used in the form of thin sheets i.e. tanupatra. Swarna patra can be used either in Ashuddha or Shuddha form ${ }^{13}$. After discussion with Rasa Vaidyas regarding the necessity of shodhana process, the decision of Samanya shodhana was taken. During pharmaceutics, the procedure of Samanya shodhana of Swarna was followed. Heating the thin sheet till red hot and its subsequent quenching in a (normal temperature) liquid media for total thirty-five times probably results in loosening the molecular bonds and makes it brittle ${ }^{14}$. It may facilitate the reaction between gold sheets and hydroalcoholic ferment. Hence the process of Samanya shodhana was carried out. 
Aishwarya Krishna Koyande and Swati Shankar Gadgil / Int. J. Res. Ayurveda Pharm. 11 (5), 2020

Table 1: Ingredients with botanical name, useful parts and quantity used for preparation of Saraswatarishta and Swarna Saraswatarishta

\begin{tabular}{|c|c|c|c|}
\hline Category & Sanskrit name/ Botanical name & Part used & Quantity \\
\hline \multirow[t]{7}{*}{$\begin{array}{c}\text { Decoction ingredients } \\
\text { (Kwatha dravya) }\end{array}$} & $\begin{array}{c}\text { Brahmi } \\
\text { (Bacopa monnieri) }\end{array}$ & Fresh whole plant & $1920 \mathrm{~g}$ \\
\hline & $\begin{array}{c}\text { Shatavari } \\
\text { (Asparagus racemose) }\end{array}$ & Root & $480 \mathrm{~g}$ \\
\hline & $\begin{array}{c}\text { Vidarikand } \\
(\text { Pueraria tuberosa })\end{array}$ & Root & $480 \mathrm{~g}$ \\
\hline & $\begin{array}{c}\text { Haritaki } \\
(\text { Terminalia chebula })\end{array}$ & Fruit & $480 \mathrm{~g}$ \\
\hline & $\begin{array}{c}\text { Balantshepa } \\
(\text { Anethum sowa) }\end{array}$ & Seeds & $480 \mathrm{~g}$ \\
\hline & $\begin{array}{c}\text { Aadraka } \\
\text { (Zingiber officinale) }\end{array}$ & Root & $480 \mathrm{~g}$ \\
\hline & $\begin{array}{c}\text { Vala } \\
\text { (Vetiveria zizanioides) }\end{array}$ & Root & $480 \mathrm{~g}$ \\
\hline \multirow[t]{2}{*}{$\begin{array}{l}\text { Sweetening agent } \\
\text { (Madhur dravya) }\end{array}$} & $\begin{array}{c}\text { Khanda Sharkara } \\
\text { (Sugar) }\end{array}$ & NA & $2400 \mathrm{~g}$ \\
\hline & $\begin{array}{c}\text { Jala } \\
\text { (Potable water) }\end{array}$ & NA & 24.576 litre \\
\hline \multirow[t]{13}{*}{$\begin{array}{l}\text { Additional ingredients } \\
\text { (Prakshepaka dravya) }\end{array}$} & $\begin{array}{c}\text { Trivrit } \\
\text { (Operculina turpethum) }\end{array}$ & Root & $24 \mathrm{~g}$ \\
\hline & $\begin{array}{l}\text { Renuka beej } \\
\text { (Vitex negundo) }\end{array}$ & Seeds & $24 \mathrm{~g}$ \\
\hline & $\begin{array}{c}\text { Pippali } \\
\text { (Piper Longum) }\end{array}$ & Fruit & $24 \mathrm{~g}$ \\
\hline & $\begin{array}{c}\text { Lavang } \\
\text { (Syzygium aromaticum) }\end{array}$ & Flower bud & $24 \mathrm{~g}$ \\
\hline & $\begin{array}{c}\text { Vacha } \\
(\text { Acorus calamus })\end{array}$ & Root & $24 \mathrm{~g}$ \\
\hline & $\begin{array}{c}\text { Kushta } \\
\text { (Saussurea lappa) }\end{array}$ & Root & $24 \mathrm{~g}$ \\
\hline & $\begin{array}{c}\text { Vasa } \\
\text { (Adhatoda vasica) }\end{array}$ & Leaf & $24 \mathrm{~g}$ \\
\hline & $\begin{array}{c}\text { Bibhitaki } \\
\text { (Terminalia bellirica) }\end{array}$ & Fruit & $24 \mathrm{~g}$ \\
\hline & $\begin{array}{c}\text { Guduchi } \\
\text { (Tinospora cordifolia) }\end{array}$ & Stem & $24 \mathrm{~g}$ \\
\hline & $\begin{array}{c}\text { Ela } \\
\text { (Elettaria cardamomum) }\end{array}$ & Fruit & $24 \mathrm{~g}$ \\
\hline & $\begin{array}{c}\text { Vidanga } \\
\text { (Embelia ribes })\end{array}$ & Fruit & $24 \mathrm{~g}$ \\
\hline & $\begin{array}{c}\text { Twak } \\
\text { (Cinnamomum zeylanicum) }\end{array}$ & Bark & $24 \mathrm{~g}$ \\
\hline & $\begin{array}{l}\text { Madhu } \\
\text { (Honey) }\end{array}$ & NA & $960 \mathrm{~g}$ \\
\hline \multirow[t]{2}{*}{$\begin{array}{l}\text { Agent for fermentation } \\
\text { (Sandhana dravya) }\end{array}$} & $\begin{array}{c}\text { Dhataki } \\
\text { (Woodfordia fruticosa) }\end{array}$ & Flower & $48 \mathrm{~g}$ \\
\hline & $\begin{array}{c}\text { Shuddha Swarna patra } \\
\text { (24 K gold sheets) } \\
\text { (For Swarna Saraswatarishta) }\end{array}$ & & $24 \mathrm{~g}$ \\
\hline
\end{tabular}

Table 2: Organoleptic parameters of Saraswatarishta and Swarna Saraswatarishta samples

\begin{tabular}{|c|c|c|c|c|}
\hline Sample Name & Sparsha (Touch) & Roopa (Colour) & Rasa (Taste) & Gandha (Odour) \\
\hline Saraswatarishta & Jalavat & Krushna varna & Tikta, Madhur & Sugandhi \\
\hline Swarna Saraswatarishta & Jalavat & Krushna varna & Tikta, Madhur & Sugandhi \\
\hline
\end{tabular}

Table 3: Physico-chemical constants of both the samples

\begin{tabular}{|c|c|c|}
\hline Parameter & Saraswatarishta & SwarnaSaraswatarishta \\
\hline pH & 3 & 2.9 \\
\hline Sp. Gravity & 1.038 & 1.030 \\
\hline Total sugars (Brix) & $40.8 \%$ & $36.8 \%$ \\
\hline Alcohol content & $7.88 \%$ & $8.93 \%$ \\
\hline Total solids & 20.12 & 21.12 \\
\hline Total phenolic content & $0.0104 \pm 0.24 \mathrm{mg} / \mathrm{ml}$ & $0.0098 \pm 0.37 \mathrm{mg} / \mathrm{ml}$ \\
\hline $\begin{array}{c}\text { Microbial load } \\
\text { (Total fungal count) }\end{array}$ & $40 \mathrm{CFU} / \mathrm{ml}$ & $70 \mathrm{CFU} / \mathrm{ml}$ \\
\hline
\end{tabular}


During formulation preparation Dhataki Jala was used instead of Dhataki pushpa ${ }^{8}$. It has been studied that the flowers of dhataki pushpa contain high percentage of tannins $(22 \%)$ and these tannins (phenolic compounds) bring enzymatic conversion to simple phenols and alcohol during anaerobic fermentation ${ }^{15}$.

Dhataki pushpa are light in weight and they tend to float on the surface of the liquid media which gives exposure to fungal growth in the process of fermentation. Hence, to avoid the fungal contact, use of Dhataki Jala is beneficial. Less amount of Pushpa are required while preparing Dhataki Jala is also one of the advantage ${ }^{8}$.

The values for physico-chemical parameters of both the samples were established. The $\mathrm{pH}$ is a negative logarithm of hydrogen ion concentration and indication of acidity of arishta sample. Fermentation of glucose results in abundant production of acidic end-product, the presence of which is detected by $\mathrm{pH}$ meter. There was change observed in the $\mathrm{pH}$ of Saraswatarishta and Swarna Saraswatarishta for thirty days (4 and 3.6) and sixty days (3 and 2.9) respectively which was then found to be stable indicating completion of the fermentation process.

This alcoholic-acid process can be correlated to extraction of active compounds from ingredients used in preparation of arishta. At the $\mathrm{pH} 4$ and below; acid soluble compounds are extracted in mild organic acids ${ }^{16}$.

According to Ayurvedic pharmacopoeia, preparation of any arishta is a process of total anaerobic microbial fermentation utilizing honey and sugar as a source of primary sugar which gets converted into alcohol. The rate of fermentation is affected by the nature of micro-organisms and source of energy. The sugars i.e. carbohydrates act as the main source of nutrition. Change in total reducing sugar and alcohol content during fermentation process are interdependent ${ }^{4}$.

At initiation of fermentation process $40 \%$ of the sugar is utilized. As the fermentation progresses, the growing yeasts use up the total reducing sugars ${ }^{10}$.

It is known that sugar content decreases during fermentation with subsequent increase in the alcohol content and reduction in density of the fermenting medium resulting decrease in the $\mathrm{pH}$ and specific gravity. Both the formulations showed different values of alcohol percentage and specific gravity. It might be due to difference in the degree of fermentation (degree at which sugar is converted into alcohol), availability of original containing microbes from the added material like sugar (Sharkara), honey (Madhu), Dhataki Jala ${ }^{8}$.

As the fermentation process undergoes a gradient increase of alcohol level, it extracts a wide range of active ingredients from the herb than any other methods of extraction ${ }^{10}$. Both the samples were subjected to evaluate the microbial load and found within the limit indicating the purity and usability of the samples. The values for $\mathrm{pH}$, specific gravity, alcohol content, microbial load etc. complied with the general API standards ${ }^{13}$.

The amount of gold from Swarna Saraswatarishta was found below the limit of quantification in congruent with no weight loss observed during the process of fermentation. The finding is contradictory to the textual reference 'Swarnapatrekshayam gate' (breakdown of gold sheets into finer particles). This is suggestive of the need of in-depth study using various forms of Swarna. This study is the first and foremost report generated for detection of Swarna from Swarna Saraswatarishta. The generated SOP will prove helpful for pharmaceutical companies and practising Vaidyas.

\section{CONCLUSION}

The SOP and physico-chemical constants of Saraswatarishta and Swarna Saraswatarishta were developed. In case of Swarna Saraswatarishta, the Swarna content was found below the level of quantification on detecting using ICP-MS technique.

\section{ACKNOWLEDGEMENT}

The authors are thankful to Dr. Yogesh Bendale from Ayurveda Rasayani, Pune for providing required amount of pure gold for the study and Dr. Suresh Jagtap (Botanist, IRSHA, Pune) for providing authentication of fresh herbal drugs; also thankful to Dr. Asmita Wele (HOD, Dept of RSBK, BVDU, Pune) and Dr. Madhuri Pawar for their constant support and guidance.

\section{REFERENCES}

1. Pillai D, Pandita N. Determination of quality standards for Draksha arishta, a polyherbal Ayurvedic formulation. Indian J Pharm Science 2016; 78(1): 129-35.

2. Shastri A. Bhaishajya Ratnavali. $2^{\text {nd }}$ edition. Varanasi; Chaukhambha Prakashan; 2016. p. 1115.

3. Rasheed A, Sri MT, Pillanayil K, Haneefa M, Pillai R, Kumar $\mathrm{A}$, et al. Formulation, standardization and pharmacological studies of Saraswatarishta: A polyhedral preparation. Pak J Pharm Sci 2014; 27(3): 551-7.

4. Kulkarni O, Giramkar S, Ligade G, Narkhede A, Mukherjee $\mathrm{S}$, Takle $\mathrm{S}$, et al. Effect of pre - sterilization on physicochemical parameters and in vitro free radical scavenging potential of Saraswatarishta. J Pharm Research 2012; 5(5): 2657-63.

5. Wagh AR, Kuvalekar AA, Jagtap RR, Giramkar SA, Jagtap $\mathrm{SD}$, Nipate SS, et al. Anticonvulsant potential of commonly practiced formulations of Brahmi (Bacopa monnieri Linn.) in Wistar rats. J Pharm Research 2013; 7(9): 787-91. Available from: http://dx.doi.org/10.1016/j.jopr.2013.09.008

6. S. Uma, S. Kavimani KVR. Effect of Saraswatarishta on Learning and Memory. Int J Phytopharm 2010; 1(1): 15-9.

7. Parekar RR, Jadhav KS, Marathe PA, Rege NN. Effect of Saraswatarishta in animal models of behaviour despair. $\mathrm{J}$ Ayurveda Integrative Medicine 2014; 5(3): 141-7.

8. Shastri D. Ayurvedeeya Aushadhikaran. $4^{\text {th }}$ edition. Shree Dhootpapeshwar Ltd.; 1964. Part 2, 34.

9. Sreelal AM, Basavaraj GY, Reshma SM. Critical Analysis on Pharmaceutics of Alcoholic Preparations (Asava-Arishta) in Ayurveda. J Ayurveda Holistic Medicine 2014; 1(9): 15-22.

10. Das C, Ghosh G, Das D. Ayurvedic Liquid Dosage form Asava and Arista: An Overview. Indian J Pharm Educational Research 2017; 51(2): 169-76.

11. Mitra A, Chakraborty S, Auddy B, Tripathi P, Sen S, Saha A $\mathrm{V}$. Evaluation of chemical constituents and free-radical scavenging activity of Swarnabhasma (gold ash), an Ayurvedic drug. J Ethnopharmacology 2002; 80: 147-53.

12. Patil Bhole T, Patil S, Wele AA. Assessment of bioavailability of gold bhasma in human participants - A pilot study. J Ayurveda Integr Med 2018; 9(4): 294-7.

13. Ayurvedic Pharmacopoeia of India. Govt. of India Ministry of health and family welfare. $1^{\text {st }}$ edition; 1999.

14. Panigrahi D. An Ayurvedic approach to general purification methods of metals with special reference to Silver. Medicinal Drug Research 2014; 2(1): 04-09.

15. Das PK, Goswami S, Chinniah A, Panda N, Banerjee S, Sahu NP, et al. Woodfordia fruticosa: Traditional uses and recent findings. J Ethnopharmacol 2007; 110: 189-99. 
16. Anna DY. Antioxidant potential of fermented biomedicines Arishtas and Asavas; an in vitro assessment. Vol. 7, Shodhananga: Inflibnet. Savitribai Phule University; 2013. Available from: http://hdl.handle.net/10603/104463.

\section{Cite this article as:}

Aishwarya Krishna Koyande and Swati Shankar Gadgil. Pharmaceutical preparation and determination of quality standards of Saraswatarishta: A Herbo-mineral Alcoholic formulation. Int. J. Res. Ayurveda Pharm. 2020;11(5):88-93 http://dx.doi.org/10.7897/2277-4343.1105147

Source of support: Nil, Conflict of interest: None Declared

Disclaimer: IJRAP is solely owned by Moksha Publishing House - A non-profit publishing house, dedicated to publishing quality research, while every effort has been taken to verify the accuracy of the content published in our Journal. IJRAP cannot accept any responsibility or liability for the site content and articles published. The views expressed in articles by our contributing authors are not necessarily those of IJRAP editor or editorial board members. 